\title{
Gendering welfare: acts of reproductive labour in applied performance practice
}

Article

Accepted Version

Bartley, S. (2019) Gendering welfare: acts of reproductive labour in applied performance practice. Contemporary Theatre Review, 29 (3). pp. 305-319. ISSN 1477-2264 doi:

https://doi.org/10.1080/10486801.2019.1615901 Available at https://centaur.reading.ac.uk/91734/

It is advisable to refer to the publisher's version if you intend to cite from the work. See Guidance on citing.

To link to this article DOI: http://dx.doi.org/10.1080/10486801.2019.1615901

Publisher: Taylor and Francis

All outputs in CentAUR are protected by Intellectual Property Rights law, including copyright law. Copyright and IPR is retained by the creators or other copyright holders. Terms and conditions for use of this material are defined in the End User Agreement.

\section{www.reading.ac.uk/centaur}

\section{CentAUR}

Central Archive at the University of Reading

Reading's research outputs online 


\section{Gendering Welfare: Acts of Reproductive Labour in Applied Performance Practice}

The period between 2010 and 2017 has been a profoundly difficult time for women in relation to work and welfare in the United Kingdom (UK). Female unemployment rose rapidly and failed to recover in line with male unemployment; ${ }^{1}$ women, and their position in the labour market, were more widely affected by changes to Lone Parent and Carers benefits; ${ }^{2}$ and poor communication about rises in the female retirement age meant that an estimated 500,000 women have been left unprepared for the delay in when they can afford to stop working. ${ }^{3}$ Alongside this the Women's Budget Group reported that by 2020 women will have borne $86 \%$ of government cuts induced by austerity policies. ${ }^{4}$ In this article, I assert the potential for representations of unemployed women and practices of socially reproductive labour in applied performance to highlight gendered experiences of welfare structures and return notions of the gendered division of labour to the public sphere. This analysis illuminates how applied performance interventions might destablise rigid distinctions of value attributed to paid and unpaid labour; and further, reconstitute notions of work in socially constructive ways.

It is particularly important to acknowledge the way in which gendered inflections of labour appear in performance given the current prevalence of narratives that express women's growing success in the paid labour market. While

\footnotetext{
${ }^{1}$ The Fawcett Society, 'The Impact of Austerity on Women', The Fawcett Society Policy Briefing: March 2012, March 2012, 7. Available at: <http://www.fawcettsociety.org.uk/wpcontent/uploads/2013/02/The-Impact-of-Austerity-on-Women-19th-March-2012.pdf> [accessed 20 July 2016].

2 Women's Budget Group, 'The Impact on Women of the 2016 Budget: Women Paying for the Chancellor's Tax Cuts', Women's Budget Group, 2016 <http://wbg.org.uk/wpcontent/uploads/2016/03/WBG_2016Budget_Response_PDF.pdf> [accessed 20 July 2016].

${ }^{3}$ The Fawcett Society, 'The Impact of Austerity on Women', 7.

${ }^{4}$ Women's Budget Group, 'The Impact on Women of the 2016 Budget', 11.
} 
such gains must be celebrated, this rhetoric of success ignores the persistence of dominant ideas around the gendering of domestic and care labour and fails to acknowledge the continued struggle of underpaid, precaritised, or unemployed women in the UK. As activist collective Feminist Fightback state, 'at the moment it appears that a liberal individualist form of feminism, easily appropriated by and absorbed into capitalism, has won out, leaving the gendered division of labour in the home fundamentally unchallenged within dominant feminist discourses and movements' ${ }^{5}$ Given the increasingly precarious position of female employment and the occlusion of the unpaid socially reproductive labour that women are involved in it is an important time to consider how representations of work, labour, and unemployment are gendered and examine how such gendered understandings emerge in applied performance practices.

I will particularly focus on the work of Clean Break Theatre Company, a women-only feminist organization in the UK. Based in North London but working across England, Clean Break was founded in 1979 and works predominantly with women who have experiences of the criminal justice sector and/or secure mental health settings. At the heart of their practice is the objective to share marginalised women's stories and foster the work of female artists. As the company state: '[w]e consistently produce groundbreaking plays dramatising women's experience of, and relationship to, crime and punishment' ${ }^{6}$ There has been a range of feminist performance scholarship exploring the company's work; however my examination of Clean Break, while recognising their engagement with criminal justice settings as

\footnotetext{
${ }^{5}$ Feminist Fightback, 'Cuts are a Feminist Issue', Soundings, 49 (2011), 73-83, 77.

${ }^{6}$ National Portfolio Application, Clean Break, 2014, unpublished Freedom of Information Request, 3.
} 
central to their company identity, seeks to expand the discussion of their work beyond prison and probation sites. ${ }^{7}$ Therefore, I deprivilege the frames of criminal justice and mental health in this analysis of their work to instead prioritise their representations of poverty and unemployment in a context of austerity. I acknowledge that these different representations and themes of engagement are correlated; it is this correlation that makes the work Clean Break undertake so rich. I specifically explore Spent (February - March 2016), a graduate touring production written by Katherine Chandler and directed by Imogen Ashby. Spent follows 'the story of three women trying to make ends meet and living in a world of easy credit and dangerous debt' ${ }^{8}$ The play tracks Denise, Nat, and Sam as they attempt to navigate a bewildering world of temporary housing, domestic violence and spiralling bills. All three characters have dependents of a sort - a brother, a partner, a child - and they undertake acts of unpaid care throughout the piece. The cast comprised of Michelle Hamilton, Eleanor Byrne, and Lydia, who are graduates of the Performance Level 2 course Clean Break offer. ${ }^{9}$ As a graduate touring production, Spent is part of a model Clean Break have been running since 2012, where graduates from the company's performance course collaborate with a writer on a short production and an accompanying workshop. Between 2012 and 2016 the company toured 7 graduate productions to 26 venues reaching 3,935 people,

\footnotetext{
${ }^{7}$ See: Alywyn Walsh, 'Staging Women in Prisons: Clean Break Theatre Company's Dramaturgy of the Cage', Crime, Media, Culture: An International Journal, 12.3 (2016), 309-26; and '(En)gendering Habitus: Women, Prison, Resistance', Contemporary Theatre Review, 24.1 (2014), 40-52; and Caoimhe McAvinchey, Clean Break (London: Bloomsbury, forthcoming).

${ }^{7}$ Clean Break, 'About Spent', Clean Break <http://www.cleanbreak.org.uk/productions/spent> [accessed 15 June 2016].

${ }^{8}$ Clean Break, 'About Spent', Clean Break <http://www.cleanbreak.org.uk/productions/spent> [accessed 15 June 2016].

${ }^{9}$ Lydia chose not to be credited under her full name and so I am not reproducing it here.
} 
predominantly from non-traditional theatre audiences. ${ }^{10}$ Spent toured England and was performed at a number of universities and conferences during 2016. It was aimed at service providers and support services working in areas addressing issues raised in the play and included a workshop that offered an opportunity to further explore the experiences of the characters. Through an analysis of representations of unemployed women in Spent, alongside an exploration of the Clean Break's organisational structures, and an examination practice of remuneration of participant-performers this article argues for the potential of applied practice to perform the value of reproductive labour while concurrently noting the socio-ethical complexity of championing reproduction when it is economically and socially undermined in a the wage-labour market of contemporary global capitalism.

I begin by outlining how the contemporary UK welfare system continues to gender citizens, arguing that this state apparatus inflects our understanding of gendered divisions of labour. Following this I consider how applied performance, and specifically Clean Break's Spent, can be understood as socially reproductive and how articulating the practice in this way positions it as radical in its resistance to distinctions of labour. Following this, I utilise Silvia Federici's work to contextualise Clean Break's representation of women's unemployment as indicative of a broader understanding of the complexities of female interactions with austerity policies, particularly the privileging of their role in reproductive labour. Finally, attending to an analysis of funding and payment, I consider the economies at play in applied performance, exploring how the work involved in such projects might be constituted

\footnotetext{
${ }^{10}$ Clean Break, National Portfolio Application, 3.
} 
as reproductive labour, or more specifically care work, and thus how that might affect the value structures embedded in this form of performance. Examining representations of unemployment and practices of socially reproductive labour reveals applied performance's capacity to both perform acts of care and, as a discipline, embody a care-full practice that unsettles traditional forms of value and responsibility but also locates applied performance itself as a precariously placed practice.

\section{Gendering Welfare}

There is a substantial amount of feminist literature which investigates the implications of the welfare system as a gendering structure. ${ }^{11}$ However, political science scholar Diane Sainsbury notes the lack of intersection between mainstream sociological analysis of welfare regimes and feminist scholarship: '[t]he units of analysis in the mainstream literature have been the individual or various collectives - classes, occupational groups, generations or households. Seldom have these gender-neutral units been broken down by sex'. ${ }^{12}$ Over twenty years on from Sainsbury's statement, The Women's Budget Group highlight the persistent lack of attention to the gendered implications of austerity policies: ' $[\mathrm{t}]$ he distributional analysis produced alongside the 2016 Budget fails to adequately analyse the impact on women and men, either as individuals or across different types of households,

\footnotetext{
${ }^{11}$ See Gender and Welfare State Regimes, ed. by Diane Sainsbury (Oxford: Oxford University Press, 1999); Gender, Welfare State and the Market: Towards a New Division of Labour, ed. by Thomas Boje and Arnlaug Leira (London and New York: Routledge, 2000); Gillian Pascall, Gender Equality in the Welfare State? (Bristol: Policy Press, 2012).

${ }^{12}$ Diane Sainsbury, Gendering Welfare States (London: Sage, 1994), 2.
} 
despite having been shown methods that are straightforward to use'. ${ }^{13}$ As such, successive Coalition and Conservative government policies have failed to adequately address the impact of gender in relation to welfare.

Socialist feminists such as Elizabeth Wilson and Hilary Land identified patriarchal structures of labour as embedded in, if not acutely intensified by, the introduction of welfare policies derived from the 'The Social Insurance and Allied Services Report' (1942), ${ }^{14}$ a report credited as foundational the development of the National Insurance Act in 1946, and the establishment of the modern UK welfare State. ${ }^{15}$ Problematically, to access unemployment insurance individuals had to pay into the scheme through a tax on their waged work. As such beneficiaries were to be waged workers rather than, as happened with the provision of healthcare, their status as citizens standing as sufficient qualification. ${ }^{16}$ Contributions-based social security was therefore entwined with the gendered division of labour and constituted an economic structure that impeded women securing financial independence. In the domestic labour debate Silvia Federici decried the 'patriarchy of the wage'; social feminists critiquing the introduction of welfare reform in 1946 may well decry the patriarchy of the benefit payment.

\footnotetext{
${ }^{13}$ Women's Budget Group, 'The Impact on Women of the 2016 Budget', 3.

${ }^{14}$ See: Elizabeth Wilson, Women and the Welfare State (London: Tavistock, 1977); and Hilary Land, 'The Family Wage', Feminist Review, 6 (1980), 55-78.

15 'The Social Insurance and Allied Services Report' produced by William Beveridge and now commonly known as the Beveridge report.

${ }^{16}$ For those unable to pay into the contributions system, The National Assistance Act 1948 was introduced to replace the Elizabethan Poor Law 1601. This act sought 'to make further provision for the welfare of disabled, sick, aged and other persons' and provide accommodation and assistance to those that were deemed destitute.
} 
Since 1946 a number of changes to enable equity across genders in their experience of welfare support have be introduced in the UK. ${ }^{17}$ However, since 2010 welfare reforms and budget cuts, particularly in relation to caring responsibilities, risk a return to the construction of the woman as precariously placed in relation to social security. In 2010, the Coalition government froze increases in Universal Child Benefit until April 2014, inducing a real terms cut of over ten per cent, and in 2013 Universal Child Benefit was abolished. The Fawcett Society have stated:

If, as the evidence suggests, second earners - mostly women - are priced out of the labour market by this change alone, placed alongside other reductions to the support available to working families this policy will reinforce the highly regressive breadwinner/homemaker model of family life. Such a move diminishes both women's economic autonomy and their potential to engage in public life, including in positions of power and influence. ${ }^{18}$

This serves to reconstitute women as domestic labourers and, potentially, as dependents. In such political and economic context, what are the stakes of engaging unemployed women in applied performance projects? Further, what is the political efficacy of persistently depicting female subjects engaged in unpaid reproductive labour?

\footnotetext{
${ }^{17}$ The Equal Pay Act 1970 legislated for equity between genders in regards to pay and employment conditions. More recently the New Labour government's introduction of the National Minimum Wage increased maternity rights and Universal Child Benefit. Additionally, European policies around gender equality have been influential in challenging gender disparity in the UK. ${ }^{17}$

${ }^{18}$ The Fawcett Society, 30.
} 


\section{Conceptualising Applied Performance as Social Reproduction}

Applied performance is often embedded and enmeshed in caring structures, populated by supportive workers who engage in professional or personal acts of care. Beyond the individual or organisational acts of care that occur within applied contexts, the practice itself, and its accompanying economic characteristics, can be conceptualised as a type of social reproduction and a labour of care. This has become increasingly clear given the growing number of arts organisations now tendering for contracts to deliver previously state administered social services. This shift is evident in, for example, Arts Council England's Cultural Commissioning Programme (2013-17), which worked with 350 cultural organisations to promote public service commissioning of creative companies. ${ }^{19}$ To be clear, I do not subscribe to the belief that state provision should be replaced by, or in competition for funding with, arts provision. Indeed, the concurrent defunding of public services and the arts represent a dual disinvestment in the social and cultural life of the UK. Instead what this article seeks to illuminate is how arts practices might be understood to be fulfilling a socially reproductive role in a way that is not currently acknowledged within narrow discourses that attest to the utility of the arts practice as an instrument of the state. Rather, I assert the radical potential of social reproduction as a way to challenge the co-option of applied performance into neoliberal agendas of instrumentality in service to the smooth running of capitalism. As such, conceptualising applied performance as care work intersects with Marxist

\footnotetext{
${ }^{19}$ National Council for Voluntary Organisations, 'Cultural Comissioning Programme', NCVO $<$ https://www.ncvo.org.uk/practical-support/information/public-services/cultural-commissioningprogramme>
} 
considerations of labour, responsibility, and value. Does applied performance as a discipline echo or disrupt the value systems attributed to waged labour and unwaged acts of care or reproduction?

James Thompson appeals to practices of care in community performance in his work on the 'aesthetics of care', which he defines as

a set of values realised in a relational process that emphasise engagements between individuals or groups over time. It is one that might consist of small creative encounters or large-scale exhibitions, but it is always one that notices inter-human relations in both the creation and the display of art projects. $^{20}$

Such a definition aptly describes the nature of Clean Break's work, which cultivates supportive relationships between those involved in a project, while also privileging the importance of caring relationships in their productions. I build on Thompson's work in recognising the affective value of applying frameworks of care to such practices in order to emphasise the 'mutual activities of sharing, support, co-working and relational solidarity within a framework of artistry or creative endeavour'.$^{21}$ Further, given the particular field of performance and austerity, I consider how economies of care operate within applied practice.

Clean Break is deeply embedded in the community within which they work; the performance that the company produce as part of the education

\footnotetext{
20 Thompson, 437.

${ }^{21}$ Ibid., 438.
} 
strand of their work will often tour to service users, people who themselves face issues raised by the work. This performance of community back to itself is a practice that has been critically understood as imbued with care and a potential value for that community. ${ }^{22}$ Alternatively, Spent was created and produced in collaboration with participant performers from the community of women at Clean Break but toured instead to service providers; and yet, such practices remain located around a practice of care. The production can be aligned with ethicist Carol Gilligan's definition of caring which 'requires paying attention, seeing, listening and responding with respect. [...] Care is a relational ethic, grounded in a premise of interdependence. But it is not selfless'. ${ }^{23}$ By presenting this performance to providers Clean Break sought to invoke relational practices of care through requiring professionals to recognise their position in an interdependent web of care and to witness and respond to the needs of the women. In doing so 'it is not selfless'; the work Clean Break produce is infused with an agenda, above anything else, to fiercely fight for the needs of their participants. In this sense, the work is never altruistic but in fact always seeking something, namely positive change for the women they represent.

In seeking to promote positive change, Spent deployed the labour of participant-performers in order to facilitates the training of social and cultural workers. The performance is an enactment of care for the community Clean Break

\footnotetext{
${ }^{22}$ See, for example, Performance and Community: Case Studies, ed. by Caoimhe McAvinchey (London: Bloomsbury, 2013); Helen Nicholson, Applied Drama The Gift of Theatre (Basingstoke: Palgrave Macmillan,2005); Petra Kuppers, Community Performance: An Introduction (Oxon: Routledge, 2007). ${ }^{23}$ Carol Gilligan, Joining the Resistance (Cambridge: Polity, 2011), 23.
} 
seek to support and concurrently at the service of those professional care workers.

Thus, the participants undertake a kind of reproductive labour which allows the care worker to improve their own working practice.

This particular tour, we wanted it to be more about service providers, partly because of the script [...]. [W]e just made the decision at the beginning when we were selling it that we wanted it to be for providers rather than users. ${ }^{24}$

Clean Break producer Emma Waslin identifies that this decision around Spent was due to the understanding that in this instance, these three interwoven stories of domestic abuse, debt, and homelessness enact a more valuable function when shared with service providers. This was further confirmed by Anna Herrman, Executive Director of Clean Break, who explained that the decision to tour the work to service providers was led by the desire to bring about change in the system and the practice of professionals. ${ }^{25}$ The company thus sought to engender a deeper understanding of the struggles faced by some women and so cultivate a more caring system and a more informed provision of care from workers who will encounter women in similar positions, in their daily work.

In a description of Spent on the CLINKS website the production was advertised as,

\footnotetext{
${ }^{24}$ Waslin, unpublished interview.

${ }^{25}$ Anna Herrman, email exchange with the author, 15 March 2018.
} 
available as a training package to book for conferences, seminars and staff training [...]. The play is performed by women affected by the Criminal Justice System and focuses on the theme of women, austerity and debt. The package is for frontline staff, managers, volunteers, advice workers, support staff and others who want to improve their practice; it uses the play as a stimulus for discussion and critical reflection, and is designed to help you reflect on and identify successful strategies to support women facing issues of debt and poverty. ${ }^{26}$

Spent was therefore presented as a 'package' for the training of staff working in relevant sectors. Performers are working to provide for the continued professional development of their audience; that is, the aims of the production are to address the situation facing women in austerity and to improve the responses of these service workers' to situations and persons. As such Spent contributes to the 'reproduction' of such workers with performers tending to the development, maintaining, and nuancing of the quality of work that the attendees are able to provide. This is in contrast to mainstream theatre, which Nicholas Ridout's identifies in postindustrial modernity as 'one group of people spend their leisure time sitting in the dark to watch others spend their working time under lights pretending to be other people' ${ }^{27}$ Alternatively, Spent is two groups of people at work, both audience and performers, in the institutional strip lighting of classroom or community hall, and

\footnotetext{
26 'CLINKS MEMBER'S NEWS: using the arts to support women', Clinks, 22 January 2016. Available at: http://www.clinks.org/clinks-light-lunch-issue-422-22nd-january-2016\#memnews4 [accessed 20 December 2016].

${ }^{27}$ Nicholas Ridout, Stage Fright, Animals and Other Theatrical Problems (Cambridge: Cambridge University Press, 2006), 6.
} 
although the performers are indeed pretending to be other people there is an overlapping of their experiences and those of the fictional women they represent. Such performances disrupt the parameters of work and leisure, engaging in a kind of reproduction of labour that supports this post-industrial economic cycle, whilst remaining partially removed from it.

Further than reproduction, I propose that this is applied performance as what Joan Tronto might term a kind '[p]olitical "care work"' in that it 'requires that those responsible for the allocation of care responsibilities throughout society are attentive to whether or not those processes of care function'.$^{28}$ Spent thus fosters the 'attentiveness' of those in caring roles and allows them to reflect on how their care is distributed. Recounting a performance with a mental health organisation Waslin commented,

A lot of people in the audience felt a little bit frustrated because they felt we were saying that their jobs weren't being fulfilled. Because essentially we're saying the solution isn't good enough because there's too many people in this situation. It was tough, there was a twist within the workshop where someone eventually said "oh I get it", and then everyone else sort of got it too. But it took all the way up until maybe 30 minutes into the workshop, and we were really pushing through. ${ }^{29}$

The service providers in this situation felt the work criticised their practice, in actuality it was an attempt to acknowledge larger structural struggles people are

\footnotetext{
28 Joan Tronto, Caring Democracy: Markets, Equality, and Justice (New York and London: New York University Press, 2013), 55.

${ }^{29}$ Waslin, unpublished interview.
} 
dealing with and attempt to collaborate on ways to navigate these difficulties. In this sense I would argue that Spent, while it was engaged in a form of reproductive labour that may have the potential to reinforce the continuation of the worker in service to capital, helped to create the space of 'political care work' to which Tronto refers. It enables a reflection on how care is distributed and enacted in society. Further, it demonstrates how applied performance can operate to bring the labour of reproduction out from the private and into the public sphere. This is 'reproduction' enacted in a societal forum and so disrupts the occlusion and subsequent devaluation of it as a vital form of labour.

\section{Performing Unemployed Women's Labour}

The domestic labour debate that emerged in the late 1960s argued that labour practices were complicit in the reproduction of gender difference and subsequent divisions of power. Throughout the 1970 s there was a feminist movement instigated by activists and scholars such as Selma James, Mariarosa Dalla Costa, and Leopoldina Fortunat, all leaders in the Wages for Housework campaign, against the assumed inevitability of unpaid reproductive work and domestic labour. ${ }^{30}$ The private sphere thus became a contested site of anti-capitalist struggle. My focus here is on the role of the public sphere, in this instance the structures and practices of the welfare

\footnotetext{
${ }^{30}$ See, Selma James, Sex, Race and Class, The Perspective of Winning: A Selection of Writings 19522011 (Oakland: PM Press, 2012); Mariarosa Dalla Costa, Family, Welfare, and the State: Between Progressivism and the New Deal (Edinburgh: Common Notions, [1983] 2015); Leopoldina Fortunati, The Arcane of Reproduction: Housework, Prositution, Labour and Capital (Brooklyn: Automedia, 1995).
} 
state, in underpinning such gendered divisions of labour both historically and in the early twenty-first century.

In her demand for the recognition of domestic labour as contributing to the foundation of capitalist production Federici notes 'the reproduction of labour power involves a far broader range of activities than the consumption of commodities, since food must be prepared, clothes have to be washed, bodies have to be stroked and cared for'.$^{31}$ The production of Spent in 2016 corresponded with the eighth successive year where foodbank usage rose in the UK; the Trusell Trust announcing in April that during the 2015/2016 financial year it provided 1,109,309 three-day emergency food supplies to people in crisis. In its presentation of the reproductive labour involved in producing and preparing food Spent brings into focus feminist critiques of the uncritical 'maintenance' of the (male) labourer posed in Marxist thought.

The character of Denise, who is focused throughout the play on gathering enough money to feed her daughter, exemplifies a widely felt experience of unemployment and austerity in the UK post-2010,

DENISE I've got $75 p$ in my pocket and a list that tells me I need bread, milk, bog roll and bananas. ${ }^{32}$

\footnotetext{
${ }^{31}$ Silvia Federici, Revolution at Point Zero: Housework, Reproduction, and Feminist Struggle (Oakland: PM Press, 2012), 96.

${ }^{32}$ Katherine Chandler, unpublished Spent script, 2016. Kindly provided by Clean Break.
} 
Indicative of the tension between care and austerity, this shopping list is a recurrent motif throughout the play, and turns into a constant calculation, an always impossible sum:

DENISE Forty nine pence and the $75 p$ that's in my pocket.

Bread, milk, bog roll and bananas.

She's hungry. ${ }^{33}$

Denise's character consistently conducts these calculations around this list of essentials and in relation to her daughter whom she is trying to feed. Gradually the list decreases as Denise is forced to do the work of reducing these four essentials to two:

DENISE For a second I think if I stare at it for long enough it might double. Like I'm Dynamo or something.

$[\ldots]$

Milk 75p, Bread 55p that's $f 1.30$.

I look at the money.

Dynamo.

$[\ldots]$

No Bananas. Not today I tells her. ${ }^{34}$

33 Ibid.

${ }^{34}$ Ibid. 
Throughout the play Denise makes these calculations, shifting between what she can afford and what is absolutely necessary for the continued subsistence of both her and her daughter. Karl Marx conceptualises labour power as 'a capacity of a living individual; its production presupposed his existence; and therefore the production of labour is dependent upon the worker's reproduction of himself, upon the worker's maintenance'.$^{35}$ In her ostensibly non-labouring status Denise struggles to ensure her own and her daughter's reproduction through provision of food and shelter. This character continually tries to establish the value of their lives in a context of austerity in which rhetoric around 'generations of worklessness' serves to render individuals worthless. ${ }^{36}$ Alongside unsettling notions around value, with her persistence in the reproduction of the non-labourer, the representation of Denise is indicative of feminist critiques of Marxist conceptions of 'reproduction'. As Federici argues, Marx's analysis fails to differentiate between 'commodity production and the reproduction of the workforce', that is, to produce and maintain a workforce they must be fed, washed, cared for, and sheltered. ${ }^{37}$ Such critiques draw attention to the gendered stratification of labour and gave rise to the domestic labour debate, which I referred to above. Denise's calculation in the play, then, can be read through two subversive frames: initially as the inversion of Marx's cycle of reproduction of the labourer, in her base calculation of benefit payment and food provision we witness the acute struggle involved in reproducing the non-labourer; further, in the

\footnotetext{
${ }^{35}$ Karl Marx, Capital, Volume 1: A Critique of Political Economy, trans. by Samuel Moore and Edward Aveling (New York: Dover Publications, [1908] 2011), 158.

${ }^{36}$ Tracy Shildrick, Robert MacDonald, Andy Furlong, Johann Roden, and Robert Crow, 'Are 'Cultures of Worklessness' Passed Down the Generations?' (London: Joseph Rowntree Foundation, December 2012).

${ }^{37}$ Marx, 92.
} 
performance of this constant calculation we see, even prior to preparation, the labour of obtaining food in a context of austerity. As such Spent asserts the reproductive labour of an unemployed woman, perpetually 'working out' these figures.

As devastating austerity measures continue to impact the most vulnerable in our society the apparatus of social reproduction embedded in the State is failing. This is startlingly depicted in Spent, particularly in the character of the old woman who physically disintegrates as the play progresses,

NAT The old woman. She's skin and bone. Her ring is loose on her finger like its hula hooping. So I takes her some chips.

But I have to pretend they're for me and I'm full. She knows what l'm doing. She tells me she don't eat. I tells her she has to eat, there's places she can go to get food, I been there myself. I say she'll starve to death. ${ }^{38}$

The character of Nat bringing food to this old woman is indicative of the informal collective networks of care which are emerging across the UK in an effort to deal with situations of desperate poverty. As I noted above foodbank usage in the UK has risen rapidly over the past eight years, alongside this The Food Foundation reported that in 2014 ' $5.6 \%$ of people aged 15 or over in the UK reported struggling to get enough food to eat and a further $4.5 \%$ reported that, at least once, they went a full

\footnotetext{
${ }^{38}$ Chandler, Spent.
} 
day without anything to eat' ${ }^{39}$ This figure amounts to 8.4 million people. The character of Nat thus highlights the reality of food poverty in the UK and stands as representative of practices of going without so others can eat. Save the Children have found $61 \%$ of parents in poverty have cut back on food, with $26 \%$ having skipped meals over the past 12 months, and $12 \%$ had cut back on food for themselves so their children have enough to eat. ${ }^{40}$ This moment in Spent is therefore a double performance, in both the participant performing the scene but also the character of Nat performing her fullness; this latter layer being resonant with everyday performances orbiting food poverty in the UK. As Tronto notes,

By analysing care relationships in society, we are able to cast into stark relief where structures of power and privilege exist in society. Because questions of care are so concrete, an analysis of who cares for whom and what reveals possible inequalities much more clearly than do other forms of analysis. ${ }^{41}$

An examination of acts of care exposes the economic, social, cultural disparities embedded in society. As such, the depiction of Nat underscores the inequalities that manifest in food poverty and points to the increasing prevalence of networks of local support offering basic services where the state has retracted provision. As an organisation Clean Break themselves are part of a cycle of food redistribution. They receive free food from Fair Share to provide lunch every day for their participants

\footnotetext{
${ }^{39}$ Anna Taylor and Rachel Loopstra, 'Too Poor To Eat: Food Insecurity in The UK' (London: The Food Foundation, 2016), 1.

${ }^{40}$ Graham Whitham, 'Child Poverty in 2012: It Shouldn't Happen Here' (London: Save the Children, 2012), 8.

${ }^{41}$ Tronto, 174-5.
} 
onsite. Acknowledging the myriad of ways in which Clean Break represent food poverty and also are part of the system which fights it further highlights the intensifying labour involved in accessing food in 2016.

Spent depicts struggles which Federici highlights 'are being fought by women who, against all odds, are reproducing their families regardless of the value the market places on their lives, valourizing their existence, reproducing them for their own sake, even when the capitalists declare their uselessness as labor power' ${ }^{42}$ In doing so Clean Break are able to call attention to these women and enable a platform for their stories to be shared, recognised, and valued beyond the ideals of the market or the welfare state. Indeed, when held against the homogenising constraints of the historical construction of women in welfare discourse Spent offers representations of "deviant women": all unmarried, one a single mother, one an elderly homeless woman and none of them either working or settled in the family model of male breadwinner/female homemaker. Yet, these women are framed positively, depicted toiling to reproduce their families (brothers, partners, children) and mark their value even when others construe them as worthless.

\section{Economies of Reproduction, Structures of Care}

Further to the dynamics of reproduction inherent in applied performance practice and represented in Spent, the position of the performers as technically unwaged further resonates with the reproductive labourer, unacknowledged in their contribution to the cycle of capital. In this instance, the 'unpaid' labour of the

\footnotetext{
${ }^{42}$ Federici, 92-3.
} 
performer participants supports the paid labour of applied performance practitioners and the generation of funding revenue for Clean Break as a company. Exploring the financing of participation and remuneration of labour in order illuminates an ambivalence around the payment of the women as participants in such performance. As participants in an arts project, these performers work outside of waged production, partly due to their position as benefit recipients. Waslin explained the difficulties the company had faced in relation to the payment of graduates for performing. Given that three actors tour the country, performing a maximum of three days per week over a two-month period I asked how they were paid for their work, she responded by outlining the complex position which organisations who work with the unemployed are in,

What's interesting about employment is that to employ people who are on benefits messes up their benefit. [...][B]ecause actually to come off benefits to go back on the benefit sometimes means that, because of the system, there might be two months where they don't get any benefit or any bursary or any money and we just can't be the reason why they lose money. ${ }^{43}$

The structures of welfare support in this context thus prevent the performers from being paid a wage for a short period of time due to the financial implications for their State benefits. In this instance the complexity of explaining the situation of

\footnotetext{
${ }^{43}$ Emma Waslin, Unpublished interview with the author, London, September 2016.
} 
Clean Break performers to Jobcentre Plus led the company to instead provide payment in bursaries. For the Spent tour Clean Break allocated, in addition to travel and subsistence costs, $£ 400$ for each performer to support the performers in pursuing their continuing development. ${ }^{44}$ This amount was not given to participants as money, rather one participant received a tablet, another a contribution towards a college course she wanted to undertake. ${ }^{45}$ In having to navigate the benefit system that their performers depend on, Waslin commented, 'we are not the people who go to the offices to talk about the benefit, they have to do that so we're actually giving them more life work to do than actually we need to be'. ${ }^{46}$ Clean Break recognise the time that would need to be expended to explain such a contract to Jobcentre Plus and are aware of the potential threat to performers' income it would present. This example also points to the broader structural issue of compensating part-time and precarious workers. Department for Work and Pensions need to become more responsive to shifting such structures and patterns of work. At present involvement in any paid work will negatively impact your benefit; if that work is over 16 hours you will not be able to claim Jobseekers Allowance. ${ }^{47}$ Participation in Spent thus may thus have led to payments being stopped and a participant being ineligible to reapply for benefit until after the tour finished. Additionally, this application for benefit could take up to six weeks to process before any funds reach the claimant.

In not being able to pay the women involved in Spent Clean Break were

\footnotetext{
${ }^{44}$ Clean Break, Spent Budget, unpublished Freedom of Information Request, 2016.

${ }^{45}$ Waslin, interview with author.

${ }^{46}$ Waslin, interview with author.

${ }^{47}$ Department for Work and Pensions, 'Jobseekers Allowance: Elligibility', gov.uk <https://www.gov.uk/jobseekers-allowance/eligibility> [accessed 1 November 2018].
} 
required to disguise, or rather remodel, the remuneration that they were able to provide. As Thompson notes, when trying to embed care into community arts practice

Decisions about accessibility [...] are not mundane organisational matters, but crucial ethical propositions. In being taken in reference to the ethics of care, they will imbue the project with an affective sense of the importance of mutual respect and regard. ${ }^{48}$

Such material considerations are crucial to practice that enables participation and supports participants, these concerns are particularly acute with performances that directly engage with unemployment and austerity. Within the confines of an inflexible welfare system and a rigid labour structure, the opaque modes of payment within Spent could contribute to a devaluing of the kind of reproductive labour which such applied performance projects engage in. Working with unemployed participants causes concepts of waged and non-waged to collide and blurs distinctions of productivity in a capitalist labour market. As Thompson notes above, there is an ethics entrenched in material and organizational decisions central to projects establishing 'mutual respect and regard'. Similarly, labor theories of value celebrate 'the worth and dignity of waged work', identifying such labour as 'entitled to respect and adequate recompense' ${ }^{49}$ Both paid work and material decisions in

\footnotetext{
48 James Thompson, 'Towards an Aesthetics of Care', RIDE: The Journal of Applied Theatre and Performance, 24.4: 430-441, 438.

${ }^{49}$ Gus Tyler in Kathi Weeks, The Problem with Work: Feminism, Marxism, Antiwork Politics, and Postwork Imaginaries (Durham: Duke University Press, 2011).
} 
applied performance are therefore inherently bound up with notions of respect. In offering participants bursaries Clean Break offered a resourceful alternative to a wage that seeks to articulate a respect for the labour of the participant performers involved. Thinking more broadly about applied performance, while the role of waged participation remains ambiguous, I urge practitioners to consider how we can publicly assert the worth of the labour participants engage in and reflect on how notions of respect is entwined with notions of the waged and the non-waged.

Beyond the participants and the creative work that Clean Break are engaged in there is a value placed on care in the structural organisation of the company itself. There is a desire and drive among practitioners to support women's participation and when companies have the capacity and awareness to provide comprehensive provision they allow these women's perspectives to be represented in performance projects. For example, between April 2013 and March 2014 Clean Break spent $£ 37,643$ on Student Support. ${ }^{50}$ Clean Break has two student support workers (their salaries are not included in the figure I quoted above) who focus on providing help for participants in a range of different areas. Given the particular remit of Clean Break to work with participants who have encountered the criminal justice and/or mental health system there is a focus within this service on assisting students with issues related to probation and challenging/offending behaviour. However, they attend to a range of issues that affect women more broadly, particularly those relying on the welfare system and clients who may have complex lives. Prior to joining any of the programmes Clean Break offer there is a two-stage assessment

\footnotetext{
${ }^{50}$ Clean Break, 2013-2014 Management Accounts, unpublished Freedom of Information request, 2016.
} 
process which instigates the holistic process of care offered by the organisation. In the initial assessment women work with student support to identify their suitability for engaging with the company and inform them of any additional emotional, learning, or medical needs they may have. In the second stage of assessment participants detail: specific issues which they might need help with such as debts, finance, employment issues, mental health; alongside which they set out their reasons for involvement and aspirations such as network, self esteem, confidence, getting qualifications. This process allows the company to offer support towards supporting women with these issues and also enables them to signpost women to further support services. Thus, alongside funding for travel and childcare as a company, then, Clean Break offers a range of support that enables women's involvement. Further, this financed support system is an overt form of economic recognition of women's care work embedded in the practice of Clean Break.

This article explores the specific coupling of artistic delivery and pastoral support that is present in the work of Clean Break; but, I propose that the company are indicative of practice occurring across the field of applied performance. The position of applied practice as embedded in social contexts and/or potentially collaborating with participants who are accessing social provision means that applied performance is regularly bound up with practices of pastoral support and signposting to social provision. In a landscape of retracting public services, it is important to consider how performance practices encounter and support individuals with increasingly complex needs. Included in the Clean Break's strategic aims is to '[p]rovide a comprehensive support service for the women they work with, offering 
practical, financial and emotional support, in partnership with specialist organisations' ${ }^{\prime}{ }^{1}$ This demonstrates that the provision of care is a central aim of the organisation, and beyond artistic and educational objectives they signpost participants to link up with other organisations for 'practical, financial and emotional support'.$^{52}$ The company's 2014/15 annual report identifies the expanding need for such support in a context of austerity:

Our Student Support Team has been meeting increased need (particularly in housing, debts and benefits) as a result of austerity, cuts and changes to public and frontline services has been a key focus of the year as well as working in partnership with a range of arts and support agencies which share our aims and a commitment to working with vulnerable women. ${ }^{53}$

This demonstrates how, beyond such overt instances of arts companies tendering for public service contracts, cultural organisations are filling the gaps of social security provision, facilitating people to access housing, debt, and benefit advice. In a context where women's services are being defunded and deprioritised by the Conservative government, arts organisations like Clean Break are utilising social justice funding to support vulnerable women with housing, debt and benefit assistance. They are also providing a safe, women-only space, in which to facilitate

\footnotetext{
${ }^{51}$ Clean Break, Clean Break Programme 2012-15, unpublished Freedom of Information request, 2016, 7. ${ }^{52}$ Clean Break, Annual Report 2014-2015, 10. Available at: http://beta.charitycommission.gov.uk/charity-details/?regid=1017560\&subid=0 [accessed 15 June 2016].

53 Ibid.
} 
their service users' engagement with other providers who offer specialist assistance in a range of different areas.

\section{Funding and Value in Applied Performance}

Finally, I want to reflect on how applied performance might share some similarities with the systemic underfunding of care work and consequently make such performance implicitly precarious in the current hostile public funding landscape in the UK. In 2011 the Women's Resource Centre found: '70\% of women's organisations felt that being women-only made it more difficult to access funding'; ' $52 \%$ of women's organisations have been forced to reduce their service provision'; ' $95 \%$ of respondents face funding cuts or a funding crisis in the next year and $25 \%$ said that further cuts would result in closure' ${ }^{54}$ I consider the intersection of applied performance and female-focused/female-led organisations and propose this has the potential to contribute to an underfunding of projects and subsequent scarcity of representations of unemployed women onstage.

In many ways Clean Break has grown significantly over the past five years: fostering partnerships with the RSC, Soho Theatre, and the Donmar Warehouse; and cultivating links with educational institutions such as City \& Islington; and over 201516 the organisation saw an $18 \%$ increase in the number of women they engaged. ${ }^{55}$ This expansion has been underpinned by a strong relationship with Arts Council England, where they hold National Portfolio Organisation status and have been

\footnotetext{
${ }^{54}$ Women's Resource Centre, 'Women-only services: Making the Case' (London: WRC, 2011), 2-3.

${ }^{55}$ Clean Break,Annual Report 2014-2015.
} 
successful recipients of Catalyst funding. ${ }^{56}$ However, in the 2015-16 financial year

Camden Council were no longer able to fund the company; a move indicative of broader cuts to local authority funding of the arts in the UK, which have had a devastating effect on provision, with Arts Council England reporting a 19\% cut to arts funding across London boroughs between 2010 and $2015 .{ }^{57}$ In responding to the shift in the funding landscape the organisation is undergoing a period of transition in order to collaboratively determine the kind of work the company undertakes.

Clean Break are indicative of the precarity of applied performance, in this instance projects which particularly attend to the concerns of oppressed women, in current funding contexts. More broadly, ACE announced that between 2011 and 2014 they spent $£ 14$ million on 'bail out' grants for arts organisations that were in financial crisis. ${ }^{58}$ This was spread across 55 theatres, galleries, music, dance, and literature organisations, few of whom were named due to 'commercial sensitivity'. 59 These organisations had to demonstrate they were at immediate and serious financial risk and that their provision was irreplaceable. Now more than ever we need to acknowledge the value of the work such arts organisations undertake and the projects they produce, even if that value is not recognised by market forces.

\section{Conclusion}

\footnotetext{
${ }^{56}$ Other major funders of Clean Break include: Big Lottery, City \& Islington, Esmée Fairbairn Foundation, and John Lyons Charity.

${ }^{57}$ Adrian Harvey, Funding Arts and Culture in a Time of Austerity (London: Arts Council England, 2016), 9-10. Available at: <http://www.artscouncil.org.uk/sites/default/files/downloadfile/Funding\%20Arts\%20and\%20Culture\%20in\%20a\%20time\%20of\%20Austerity\%20(Adrian\%20Harve y).pdf> [15 April 2016].

58 'Troubled Arts Venues get $£ 14 \mathrm{~m}$ Arts Council Bail-out', BBC News, 28 May 2014. Available at: <http://www.bbc.co.uk/news/entertainment-arts-27518118> [accessed 20 March 2017]. 59 Ibid.
} 
Reading Clean Break's Spent as a critique of the way in which women are positioned by the UK benefit system underscores the potential of applied practice to platform and perform the value of women's reproductive labour. Examining Spent's intended audience of service providers, reveals how performance concerned with social development can itself function as a kind of reproductive labour. Concurrently, analysing representations of unemployed women in Spent illuminates the insufficiency of catagorisations of employment to recognise women's labour and exposes the ongoing struggle to reproduce lives in a period of austerity. Further, my exploration of organisational structures and economies of applied performance draws parallels between unpaid care labour often associated with women and the caring/care-full work of feminist applied performance practitioners. Finally, the financial investment feminist theatre companies are making to build support systems into their practice that enable women's ongoing participation demonstrates the broader capacity of applied performance practice to create structures of care for participants beyond performance.

This article has sought to make legible the financial precarity and social productivity of both unemployed women's labour and applied performance in order to locate each as valuable and in need of increased support and attention. Feminist Fightback assert that '[a]ny feminist response to the austerity measures and their deeply gendered implications will, however, necessitate a re-focus on the home and the socially reproductive labour that takes place within $i t^{\prime} .{ }^{60}$ In navigating a landscape of austerity, applied performance has the potential to equip participants,

\footnotetext{
${ }^{60}$ Feminist Fightback, 78.
} 
practitioners, and scholars with the tools for this refocusing on importance of social reproduction. Concurrently applied performance is itself a mode of that same reproduction, a practice infused with care and attention for participants often occluded from such relational networks support but also an undervalued aspect of the economic ecology of performance and the society. This demands scholarship attend to the reproductive labour of applied arts practice and positions that practice as well placed to highlight the importance of care work within capitalist modes of exchange. 